\title{
Teke (Antalya) Sancağının Konya Vilayetinden Ayrılarak Bağımsız Hale Getirilmesi ve Idari Yönden Yeniden Düzenlenmesi ${ }^{*}$
}

\section{Kerim Sançelik **}

\begin{abstract}
O̊z
XX. yüzyıl başlarında Konya Vilayetinin beş sancağından birisi olan Teke (Antalya) Sancağ $22.370 \mathrm{~km}^{2}$ yüzölçümüne ve 350 deniz milini bulan sahil şeridine sahipti. Nüfusu 250 bin kadardı. Bu haliyle birçok bağımsız sancaktan hatta vilayetten bile daha büyük bir coğrafi ünite oluşturmaktaydı. Buna karşın sancağın büyüklüğüyle bağdaşmayan yetersiz idari organizasyonu ve vilayet merkezi Konya’ya olan uzaklığı, yönetimde ciddi aksaklıklara neden olmaktaydı. Bu durum yeni bir idari düzenleme ihtiyacını ortaya çıkarmıştı. Kaldı ki 26 Mart 1913 tarihli vilayet kanunu da daha küçük, yönetilebilir idari birimleri esas alan bir yönetim anlayışı getirmekteydi. Tüm bu gerekçelerle 12 Mart 1914 tarihinde Teke Sancağı, Konya Vilayetinden ayrılarak bağımsız hâle getirilmiştir.

Bağımsız sancakta idari teşkilatlanma uzun ve meşakkatli bir yol izledi. $\mathrm{Bu}$ süreçte yeni kaza ve nahiyeler tesis edildi. Buralarda hizmet birimleri meydana getirilmeye ve personel kadrosu oluşturulmaya çalışıldı. Öte yandan sancak hususi idaresi kurularak meclis-i umumi toplanmış ve sancak bütçesini hazırlama işine girişmiştir.
\end{abstract}

\section{Anahtar Kelimeler}

Teke Sancağı, bağımsız sancak, mülki taksimat, mahalli idareler, hususi idare.

\footnotetext{
Geliş Tarihi: 22 Ocak 2017 - Kabul Tarihi: 15 Ağustos 2017

Bu makaleyi şu şekilde kaynak gösterebilirsiniz:

Sarıçelik, Kerim (2020). “Teke (Antalya) Sancağının Konya Vilayetinden Ayrılarak Bağımsız Hale Getirilmesi ve İdari Yönden Yeniden Düzenlenmesi”. bilig - Türk Dünyası Sosyal Bilimler Dergisi 93: 85-114.

"* Doç. Dr. Necmettin Erbakan Üniversitesi, Ahmet Keleşoğlu Eğitim Fakültesi, Tarih Eğitimi Anabilim Dalı - Konya/Türkiye.

ORCID ID: 0000-0003-2827-6132

ksaricelik@erbakan.edu.tr
} 


\section{Giriş}

Osmanlı Devleti'nde kuruluş döneminde mülki yapılanmada temel idari birim olarak sancâk kabul edilmişti. Zamanla sınırların genişlemesi ve askerî gerekçelerle sancaklar beylerbeylerinin yönetimi altında birleştirilmişti. Askerî görevleri olan beylerbeylerine mülki yetkilerde verilerek eyâlet adı verilen birimler meydana getirilmiştir. Bununla birlikte herhangi bir eyalete bağlı olmayan, resmî muamelelerini bizatihi devlet merkezi ile yürüten bağımsız sancaklar da bulunmaktaydı. Bu idari yapı varlığını Tanzimat Dönemi’ne kadar sürdürmüştür.

Gülhane Hatt-1 Hümâyûnunun ilanından hemen sonra ülke yönetimi yeni baştan düzenlendi. Sancaklara muhassıl adı verilen görevliler atandı. Muhassıllar sancağı yönetecekleri gibi vergileri de doğrudan toplayarak hazineye göndereceklerdi. Fakat devletin iltizam usulünü kaldırarak adil bir sistem kurmak amacıyla giriştiği bu uygulama başarısızlıkla sonuçlandı. 1842 yllında muhassıllar görevden alınarak yerlerine kâimmekâm lar atand. Eyaletler yine valilerin yönetimindeydi. Fakat valilerin yetkileri kısıtlanarak mali işlerin sorumluluğu defterdarlara bırakılmıştı. 1842 yılı düzenlemelerinin en dikkate değer yönü köy ile sancak arasında yeni bir yönetim birimin, kazâ nın oluşturulmuş olmasıdır. Başında kadı efendinin bulunduğu adli bir ünite olan kazanın yönetimi, yörenin ileri gelenlerince seçilecek bir müdüre bırakılmışır. Ayrıca eyalet ve sancak meclisleri oluşturulmuş ve bu kurullar idari birimlerin yönetimine ortak edilmişlerdir (Çadırcı 1991: 225-241).

Tanzimat Dönemi’nde 22 Eylül 1858 tarihli Vülât-ı İzâm ve Mutasarrıfinn-i Kirâm ile Kầimmekâmlarnn ve Müdirlerin Vezâifini Şâmil Tảlimât ile ülke eyalet, liva, kaza ve karye adları ile bir takım idari birimlere ayrılmakta ve bunların yöneticilerinin görevleri ayrıntılarıyla açılanmaktaydı (Tönük 1945: 116-128, Torun 2012: 92). Talimat'ta merkeze bağlı bağımsız sancakların önceden olduğu gibi varlıklarını devam ettirecekleri belirtilmekteydi. Bu sancakların başında bulunan mutasarrıflara eyalet valileriyle aynı yetki ve sorumluluklar tanınmaktaydı. Ayrıca Talimatname idari taksimat üzerinde yapılacak değişiklik ve düzenlemelerin ancak padişah 
fermanıyla mümkün olabileceğini de vurgulamıştır ki bundan sonraki uygulamalarda bu ilkeye titizlikle uyulduğu görülmektedir.

$\mathrm{Bu}$ düzenlemelerin amacı merkezi otoriteyi güçlendirmek ve Tanzimat ilkelerinin taşrada daha iyi şekilde uygulanmasını sağlamaktı. Bununla birlikte ülkenin artan iç-dış ticaretine ve gelişen tarımına bağlı olarak ulaşım ağı ve ticaret kanallarının değişmiş olması yeni idari düzenlemeler yapılmasını zorunlu kılmaktaydı. Çünkü ülkenin farklı noktalarında yeni üretim ve ticaret merkezleri ortaya çıkmıs, eski bazı kasaba ve şehirler küçülürken bazıları oldukça gelişmişlerdi. Bunun yanında Avrupa büyük güçlerinin, gayrimüslim toplumların yönetim üzerinde etkili olabilecekleri özerk bölgeler kurdurmak için devlete yoğun baskı yapmaları da aynı döneme rastlamıştır. Nitekim bu tür baskılar neticesinde hükümet 1861 yılında Cebel-i Lübnan'a etnik-dini eşit katılım esasına dayanan bir özerklik tanınmak zorunda kaldı (Ortaylı 2007: 427-429). Tüm bu sorunlara kalıcı bir çözüm bulmak amacıyla 1864 yılında merkeziyetçi bir idari düzenleme; vilayet nizamnamesi yapılmıştır. Önce Tuna vilayetinde uygulanan ${ }^{1}$, görülen başarılar üzerine 1867 yılında birkaç bölge dışında tüm ülkede geçerli hâle gelen Nizamname, eyalet sistemini ortadan kaldırmakta en büyük idari birim olarak vilayeti getirmekteydi (Davison 2005: 158,165, Ortayli 2000: 53-63, Kırmızı 2007: 26-29). Düzenleme 22 Ocak 1871 tarihinde yeniden formüle edilerek İdâre-i Umûmiye-i Vilâyât Nizâmnâmesi olarak yayınlandı (Düstûr H.1289. I. Tertib, C. I: 625-651)². Vilayet nizamnameleri ile taşra teşkilatında görev yapan memurlarının sayısı çoğaltılmış, yeni müdürlükler ihdas edilmiş kaza, liva ve vilayetlerde birer idare meclisi kurulmuştur. Bunun yanında vilayetin genelini ilgilendiren tarım, ticaret, eğitim ve nafia gibi konularda kararlar alarak bunları hükümete bildirmek için vilâyet meclis-i umûmisi adında istişarî nitelikte bir kurul meydana getirilmiştir. Son Nizamname ile livalara, bağımsız sancaklarda olduğu gibi mutasarrıflar atanmaya başlanmış, kaymakamlar artık kazaların mülki amiri olmuşlardır. Böylece merkezî idarenin otoritesi kazaları da içine alacak şekilde genişletilmiştir (Tönük 1945: 183-199, Ortaylı 2000: 63-64, Kırmızı 2007: 31-34).

II. Meşrutiyet Dönemi'nde 26 Mart 1913 tarihinde çıarılan İdâre-i 
Umûmiye-i Vilâyât Kanûn-ı Muvakkati vilayet yönetimini yeniden düzenledi (BOA. A.(DVNSNZAM. d. 24: 1-19; Takvîm-i Vekâyi (19 Rebiyülahir 1331): n.1414; Düstûr H.1332. II Tertib, C. V: 186-216). Buna göre vilayet umumi idaresi ve vilayet hususi idaresi olmak üzere iki yönlü bir yönetim düzeni oluşturuldu. Nezaretlerin vilayetteki uzantısı daireler, merkezin temsilcisi olan ve yürütme gücünü elinde bulunduran valinin yönetimi ve denetimine bırakılmıştı. Bu yönüyle vilayet umumi idaresi bir tüzel kişiliğe sahip değildi ve merkez yönetiminin bir bölümünü oluşturmaktaydı. Oysa Kanun bir yenilik olarak vilayet hususi idaresi denilen taşınır taşınmaz mallara sahip bir tüzel kişiliği de meydana getirmiştir. Kanun, vilayeti kamu hizmeti yapan ayrı bir hukuksal yapı olarak görmekte ve onun organlarını ve yürütme kararı alma yetkisini kabul etmekteydi. Nitekim hususi idarenin bir organı olarak vazife gören meclis-i umumiler, vilayetlerde ve bağımsız sancaklarda icraî yetkilerle donatılmıştı. Bu kurullar artık vilayet/bağımsız sancak hususi bütçelerini oluşturabileceklerdi. Meclis üyelerinden seçilen encümen-i daimi, aynı zamanda vilayet tüzel kişiliğinin temsilcisi olan valinin başkanlığında çalışarak bütçede öngörülen işleri yapacaktı (Sencer 1984: 68-69, Kaştan 2016: 88). Vilayet idaresindeki yeni düzen yerinden yönetim ilkesini getirmekteydi. Kanun'un yayınlanmasının hemen ardından büyük alanları kaplayan ve birçok mülki üniteden meydana gelen bazı vilayetlerin durumunun hükümetçe yeniden ele alındığı görülmektedir. Böyle yerlerde hususi idarelerin görevlerini ifa etmede karşılaşacakları zorluklar dikkate alınarak yeni bir idari taksimat yapılmış; vilayetlere bağlı bazı sancaklar ayrılarak bağımsız hâle getirilmiştir ${ }^{3}$. Bu sancaklardan birisi de Konya Vilayetine bağlı iken bağımsız bir mülki ünite şekline getirilen Teke Sancağıdır.

\section{Bağımsız Sancak Oluncaya Kadar Teke Sancağında Yönetim}

Antalya ve çevresi Yıldırım Bayezid döneminde Osmanlı hâkimiyetine katıldıktan sonra bölge Teke Sancağı olarak teşkilatlandırıldı. XVI. yüzyılda sancak, Antalya, Finike, Elmalı, Kaş, Karahisâr-1 Teke ve Kalkanlu adlarında altı kazadan oluşmaktaydı (Emecen 1991: 233, 236). Bazı dönemlerde şehzadelerin idaresine bırakılan sancak, XIX. yüzyıla kadar Anadolu ve Karaman eyaletlerine bağlı olarak yönetildi (Karaca 2002: 43, 
44). Bununla birlikte XIX. yüzyıl başlarında Teke Sancağına çoğu zaman vezir rütbeli paşalar mutasarrıf olarak atandılar. Nitekim 1813-1838 yılları arasında sancağı yöneten 19 mutasarrıftan - sancakta 1820-1821 yıllarında idareci olan Nasuhî zâde Hacı Süleyman Ağa hariç- 18'i paşa unvanı taşımaktaydı. Öte yandan mutasarrıflara genellikle Teke Sancağı ile beraber Hamid Sancağının da yönetimi verilmiştir. Bu 19 mutasarrıftan 14 'ü her iki sancağı da beraber yönetirlerken beşi Teke Sancağını müstakilen idare etmiştir. İki sancağı idare eden mutasarrıfların kimi zaman yerlerine güvendikleri birini mütesellim olarak gönderdikleri de olmuştur. Mesela Teke ve Hamid sancakları mutasarrıfı Seyyid Mehmed Vahid Paşa 1814 yılında Teke Sancağı yönetimini mütesellim olarak görevlendirdiği Osman Ağa vasıtasıyla yürütmüştür (Özdemir 1992: 134,135, Moğol 1997: 100103). Tanzimat Fermanı'nın ilanından sonra sancaklara muhassıl unvanıyla mali ve idari yetkileri bulunan yöneticiler gönderilmiş, Teke Sancağına da bu görevle 1841 yılında Mehmet Bey atanmışır. 1842 yılından itibaren muhassıllar görevden alınarak sancakların yönetimi kaymakamlara bırakılmasına rağmen Teke Sancağında bir süre daha muhassıl unvanlı kişilerin görev yaptığı görülmektedir. İzzet Bey 1846-1847 yıllarında, Şakir Bey de 1849-1850 yıllarında sancakta muhassıllık yapmışlardır. Fakat 1842 yılı düzenlemeleri Teke Sancağını, merkezi Konya olan Karaman Eyaletine idari yönden bağlamış ve artık sancak yöneticileri eyalet valisinin kontrolüne girmiştir (Moğol 1997: 113, 114).

Daha önce üzerinde durulduğu gibi ülke yönetiminde yeni bir idari düzenlemeyi getiren 1864 vilayet nizamnamesi Tuna Vilayetinde başarıyla uygulandıktan sonra 1867 yılında ülke geneline teşmil edilmesi kararı verilmişti. Buna bağlı olarak 1867 yılında Bahr-i Sefîd, Trabzon Aydın, Ankara, Diyarbekir, Sivas, Kastamonu, Selanik, Yanya, Üsküb ve Konya vilayetleri meydana getirildi (Çakmak 2014: 47). Konya Vilayetine bağlı olan Teke Sancağı, Antalya merkez kazası ile birlikte Alanya, Elmalı, Akseki ve Kızılkaya kazalarından oluşmaktaydı (Salnâme-i Vilâyet-i Konya H. 1285: 62-66). Kızılkaya kazası kısa bir süre sonra nahiye olarak merkeze bağlanmış ve Kaş kazası teşkil edilmiştir (Salnâme-i Vilâyet-i Konya H. 1287: 61-65). 
XIX. yüzyıl sonunda Teke Sancağının idari yapısı şu şekildedir (Salnâme-i Vilâyet-i Konya H. 1317: 200-225):

Tablo 1. XIX. Yüzyıl Sonunda Teke Sancăğnın İdarî Yapısı

\begin{tabular}{llc}
\hline Kaza & Nabiye & Bă̆lı Karye Sayısı \\
\hline Antalya Kazası & Merkez & 45 \\
& İstanos Nahiyesi & 45 \\
& Kızılkaya Nahiyesi & 11 \\
& Bucak Nahiyesi & 9 \\
& Millû Nahiyesi & 23 \\
& Beşkonak Nahiyesi & 9 \\
& Iğdır maa Kardiç Nahiyesi & 15 \\
& Serik Nahiyesi & 25 \\
\hline Alaiye Kazası & Merkez & 78 \\
& Düşenbe Nahiyesi & 27 \\
& Manavgat Nahiyesi & 42 \\
\hline Akseki Kazası & Merkez & 63 \\
& İbradı Nahiyesi & 14 \\
\hline Elmalı Kazası & Merkez & 39 \\
\hline Kaş Kazası & Finike Nahiyesi & 19 \\
\hline
\end{tabular}

Teke Sancağı XX. yüzyıl başında beş kaza ve 11 nahiyeden meydana gelmekteydi. Antalya kazasına bağlı olan Bucak nahiyesi merkez kazaya uzak olması, halkın ilişkilerinin daha çok Burdur ile olması ve eşkıyalık olaylarında Antalya'dan yetişilememesi gibi nedenlerle halkın da isteği doğrultusunda 1909 yılında Burdur'a bağlandı (Uysal 2010: 107). Alanya kazasının bir nahiyesi olan Manavgat da Düşenbe nahiyesi içerisine alındı. Teke Sancağı 1914 yılı başında beş kaza ve dokuz nahiyeden oluşan bir idari ünite hâlinde yönetilmekteydi.

\section{Teke Sancağında İdari Düzenleme Önerileri}

Teke Sancağı yüzölçümü ve nüfusu bakımından diğer sancaklarla kıyas edilemeyecek bir büyüklüğe sahipti. Üstelik sancağın Akdeniz kıyısı boyunca uzanan oldukça uzun bir sahili bulunmaktaydı. Teke Mutasarrıflı̆ıının 13 Ocak 1914 (BOA. DH. İ. UM. EK. 90/70: lef 3) ve 25 Şubat 1914 (BOA. 
DH. İ. UM. EK. 90/70: lef4) tarihli iki raporundan anlaşıldığına göre sancağın yüzölçümü $22.370 \mathrm{~km}^{2}$ olup kıyılarının uzunluğu yaklaşık 350 deniz mili idi. Bu hâliyle bağımsız sancaklar olan $12.050 \mathrm{~km}^{2}$ büyüklüğündeki İzmit Sancağı ile $7.500 \mathrm{~km}^{2}$ alanı kaplayan Kale-i Sultani Sancağının toplamından daha büyük bir yüzölçümüne sahip bulunmaktaydı. Sancağın nüfusu 250 bin kadardı. Göçebelerin dâhil edilmesi ve iyi bir sayım yapılması durumunda gerçek nüfusun 300 bine ulaşacağı tahmin edilmekteydi. Raporlarda sancağın bu yapısının ve vilayet merkezi Konyàya olan uzaklığının yönetimde ciddi aksaklıklara neden olduğu vurgulanmaktaydı.

Nitekim ilk raporda uzun kıyı şeridi boyunca yer alan 75 iskelede yeterince görevli bulunmamasından dolayı yaygın bir şekilde yaşanan kaçakçlık faaliyetleri üzerinde durulmaktaydı. Mevcut personel ne mal nakliyatına ne de kıyı ve ormanların muhafazasına yetişebilmekteydiler. Özellikle İskenderiye'ye yapılan kaçak kereste ihracatı nedeniyle ormanlar yok edilmekte ve gizlice nakledilen mal ve ürünlerden gümrük gelirlerinde ciddi kayıplar yaşanmaktaydı. Gerçekten de bina ve gemi yapımında kullanılabilecek sağlam kereste Mısır'da olmadığından bu ürünler çoğu zaman kaçak yollarla bölgeden karşılanmaktaydı (Faroqhi 2008: 12). Bu durumda kaçakçılarla mücadele için 80 fen memuru, 229 bekçi başı ve 804 bekçiye ihtiyaç duyulmaktaydı. Mevcut idari teşkilat ve yetersiz kadrolarla inzibat ve asayişin sağlanması imkânsız görülmekteydi. Teke Mutasarrıfı ikinci raporunda sadece merkez kazanın coğrafi büyüklüğünün birçok sancaktan daha geniş olduğunu vurgulamakta kış aylarında hükümet dairelerine bilhassa adliyeye gelmek zorunda olan vatandaşların birçok sıkıntı çektiğini belirtmekteydi. Mutasarrıf bu olumsuzlukların giderilmesinin ancak yeni bir idari teşkilatla mümkün olabileceği kanısındaydı.

Teke mutasarrıfının yeni bir idari teşkilat önerisi aslında sancağın bağımsız hâle getirilmesi değildi. Zaten 25 Şubat 1914 tarihli raporda böyle bir istek göze çarpmamaktadır. O sancak içerisinde bir dizi düzenleme yapılmasına taraftardı. Buna göre;

1. Merkez kazaya bağlı olan İstanos nahiyesi yeni kurulacak Bozova ve Kızılcadağ nahiyeleri ile birleştirilerek İstanos merkez nahiye olmak üzere yeni bir kaza kurulması ve buraya da Sultan V. Murat'in ismine izafeten Muradiye isminin verilmesi ${ }^{4}$ 
2. İğdir Kardiç nahiyesinin güneyinde Kumluca ile Kaş kazasının doğusunda Kale adlarında iki nahiye kurulması ve bunların Elmalı’ya bağlı Finike nahiyesiyle birleştirilerek merkez Finike olmak üzere yeni bir kaza teşkil edilmesi. Buraya da Finike nahiyesinin merkezi olan kasabanın adına izafetle Reşadiye denilmesi

3. Merkez kaza mülhakatından Beşkonak nahiyesi ile Alanya’nın Düşenbe nahiyesinin birleştirilmesi ve Manavgat nahiyesinin yeniden teşkil edilerek üçüncü bir nahiye olarak bunlara dâhil edilmesiyle yeni bir kaza kurulması. Kaza merkezinin Girit'ten gelen İslâm muhacirlerinin iskân edildikleri ve Side harabeleri üzerinde kurulmuş olan ve geniş bir limana sahip bulunan Selimiye (Eski Antalya) köyü olması ve kazanın adının da bu köye izafetle Selimiye yapılması

4. Merkez kazaya bağlı Serik nahiyesinin ikiye bölünmesi ve ikinci kısımda Gebiz adında yeni bir nahiye kurulması. Ayrıca merkez kazanın güneyindeki köylerin birkaçıyla Serik'in kuzeyindeki köylerin bir kısmından Perge harabeleri üzerinde kurulmuş olan Murtana Macun köyü merkez ittihaz olunarak burada akan nehrin adına izafeten $A k s u$ adında bir başka nahiye teşkil edilmesi

5. İğdir Kardiç nahiyesinin güneyinde güzel bir limana sahip olan Kemer-Ağva köyü merkez olarak Kemer nahiyesinin kurulması

6. Antalya’nın batısındaki merkez kaza köylerinden bir kısmının katılmasıyla Çakırlar köyü merkez ittihaz edilerek Çandır namında bir nahiye teşkil edilmesi

7. Elmalı ve Kaş kazaları arasında bulunan Gömbe kasabası merkez ittihaz edilerek ve Kaş kazasının bazı köyleri de buraya katılarak Gömbe nahiyesinin kurulması

8. Elmalı kazasıyla İğdir Kardiç nahiyesinin bir kısım köyleri birleştirilerek bu köylerin ortasında yer alan Kuzca köyü merkez olmak üzere Kuzca nahiyesinin teşkili

9. Kaş'in Ilıkra-Kalamaki köyü merkez olmak üzere Kalkan nahiyesinin kurulması

10. Alanya kazasında merkezi Belen köyü olarak Demirtaş, Girenas köyü merkez olmak üzere Köprülü, Öteköy merkezli Kara Halil ve 
Kızılağaç köyü merkezinde Gedikli adlarında dört nahiyenin teşkil edilmesi

11. Akseki kazası ile alakası olmayan Yeniköy, Kirli, Gencek, Zekeriya, Derebucak ve Gönem köylerinin Beyşehir ya da Seydişehir'e ilhak olunması buna mukabil Alanyadan alınan Karabul, Eğre, Kozağacı, Senir, Namras ve Marnas köyleriyle Akseki'nin bazı köyleri birleştirilerek merkezi Sülles köyü olmak üzere Sülles nahiyesinin kurulması. Ayrıca İbradı nahiyesinin bir kısım köyleri ayrılarak merkezi Kagras köyü olmak üzere Kagras nahiyesinin teşkil edilmesi gibi öneriler sunulmaktaydı.

Teke Sancağ 1 sekiz kaza ve 31 nahiyeden oluşan bir idari birim olarak düşünülmekteydi. Sancağın mülki taksimatının şu şekilde olacağ öngörülmekteydi:

Tablo 2. Teke Mutasarriflĭgının İdarî Taksimat Önerisi (25 Şubat 1914)

\section{Antalya Kazasi}

\begin{tabular}{lllll} 
Nabiyeler & Merkezi & Nüfus & Alan $_{\text {km }}{ }^{\mathbf{2}}$ & Karye \\
Merkez nahiye & Antalya şehri & 34.535 & 800 & 16 \\
Çandır & Çakırlar & 3.424 & 700 & 13 \\
Aksu & Murtana Macun & 3.954 & 400 & 14 \\
Serik & (Kökez) Şevketiye & 5.964 & 400 & 32 \\
Gebiz & Macar & 4.785 & 900 & 20 \\
Kızılkaya & Badem Ağacı & 5.313 & 450 & 15 \\
Millü & Çil & 5.464 & 900 & 21 \\
Kemer & (Ağva) Kemer & 1.512 & 500 & 8 \\
\hline
\end{tabular}

\section{Alaiye Kazası}

$\begin{array}{lllll}\text { Merkez Nahiye } & \text { Alanya kasabası } & 8.282 & 600 & 25 \\ \text { Demirtaş } & \text { Belen } & 4.435 & 850 & 25 \\ \text { Kara Halil } & \text { Öteköy } & 2.116 & 650 & 14 \\ \text { Köprülü } & \text { Girenas } & 3.302 & 550 & 11 \\ \text { Gedikli } & \text { Kızılağaç } & 3.824 & 550 & 21\end{array}$




\section{Akseki Kazası}

$\begin{array}{lllll}\text { Merkez Nahiye } & \text { Marulya kasabası } & 13.392 & 750 & 24 \\ \text { Sülles } & \text { Sülles } & 8.370 & 600 & 27 \\ \text { İbradı } & \text { İbradı kasabası } & 7.495 & 1.300 & 8 \\ \text { Kagras } & \text { Kagras } & 3.134 & 700 & 9\end{array}$

\section{Selimiye Kazası}

$\begin{array}{lllll}\text { Merkez Nahiye } & \text { Selimiye } & 7.970 & 950 & 39 \\ \text { Beşkonak } & \text { Bozyaka } & 3.844 & 1.100 & 14 \\ \text { Düşenbe } & \text { Pazarc1 } & 8.034 & 600 & 31\end{array}$

\section{Muradiye Kazası}

$\begin{array}{lllll}\text { Merkez Nahiye } & \text { Kışla kasabası } & 5.836 & 400 & 12 \\ \text { Bozova } & \text { Zivind } & 8.123 & 450 & 19 \\ \text { Kızılcadağ } & \text { Kızılaliler } & 11.577 & 450 & 20\end{array}$

\section{Elmalı Kazası}

\begin{tabular}{lllll} 
Merkez Nahiye & Elmalı kasabası & 6.581 & 1.220 & 27 \\
Kuzca & Gödene & 2.506 & 880 & 6 \\
Gömbe & Gömbe kasabası & 4.953 & 450 & 14 \\
\hline \multirow{2}{*}{ Kaş Kazası } & & 26 \\
Merkez Nahiye & Andifli iskelesi & 10.503 & 1.050 & 17 \\
Kalkan & Ilıkra iskelesi & 8.851 & 1.370 & 11 \\
\hline \multirow{2}{*}{ Reşadiye Kazası } & & 12 \\
Merkez Nahiye & Reşadiye (Finike) & 3.634 & 650 & 16 \\
Kumluca & Kumluca (Sarı Kavak) 2.813 & 600 & 600 \\
Kale & Eynihal & 4.680 &
\end{tabular}

\section{Bağımsız Teke Sancağının Kurulması}

Teke Mutasarrıflı̆ıının kapsamlı idari düzenleme teklifinde her ne kadar sancağın bağımsız hâle getirilmesi görüşünden bahsedilmese de bu konuda bazı yetkililerin çalışmalar yaptığı görülmektedir. Zira 1912 yılında İttihat ve Terakki Cemiyeti murahhası Mehmet Ali Bey bu öneriyi resmî yollardan 
hükümete iletmişti. 1913 yılında da düşünülen bağımsız sancağı 11 kaza ve 30 nahiye olarak teşkilatlandıran bir öneri sunulmuştur (Güçlü 1998: 290). Tüm bu teklifler bir yana bu dönemde hükümette zaten büyük vilayetlerden bağımsız sancaklar kurma iradesi oluşmuş bulunmaktaydı. Çünkü 26 Mart 1913 tarihli vilayet kanunu ile hususi idareler meydana getirilmiş ve taşra yönetimi kısmî özerkliğe kavuşmuştu. Vilayetlere daha etkin bir yönetim sorumluluğu getiren yeni düzenlemenin ruhuna uygun olan daha küçük, yönetilebilir idari yapılar oluşturmaktı. Yıllık bütçe hazırlayan ve öngörülen işleri zamanında yapmakla mükellef olan hususi idarelerin çalışma sahası ne kadar sınırlı olursa başarısı da o derece yüksek olabilirdi. Nitekim büyük bir vilayet olan Aydın'dan ayrılan Menteşe Sancağı 1 Kasım 1913 tarihli irade-i seniyye ile bağımsız hâle getirildi (BOA. A. DVNS. NZAM. d. 24: 194). Bu şekilde 1906-1907 yılında beş olan bağımsız sancak sayısı 1914 yılı itibariyle 18 'e çımıştır. İşte bu süreçte hükümet sadece sancak içerisinde bir düzenleme yapmak yerine Teke Sancağını Konya Vilayetinden ayırarak bağımsız bir sancak hâline getirmeye karar verdi. Tasarı geçici bir kanun halinde Padişah'a sunuldu. 12 Mart 1914 tarihinde çıkan irade-i seniyye ile Konya Vilâyeti mülhakatından Teke Sancâğı muhassasât-ı hâzırasıyla müstakill livâ hâline ifrâğ edilmiştir (BOA. A. DVNS. NZAM. d. 24: 298; BOA. İ. MMS. 181/4 ). Durum 16 Mart 1914 tarihinde nezaretlere bildirilmiş (BOA. DH. İ. UM. EK. 87/28: lef 2) ve iki gün sonra da Takvîm-i Vekâyi ile neşredilmiştir (Takvîm-i Vekâyi 30 Rebiyülahir 1332: n. 1760). Meclisin açlmasından sonra da geçici kanun Meclis-i Mebusan ve Meclis-i Ayan tarafından görüşülerek 23 Temmuz 1914 tarihinde onaylanmış ve kanun hâline getirilmiştir (BOA. A. DVN. MKL. 58-A/96).

Teke Sancağının bağımsız hâle getirilmesiyle birlikte mutasarrıflı̆ın 25 Şubat 1914 tarihli raporunda ortaya koyduğu yeni idari düzenleme teklifi Dâhiliye Nezareti tarafından bazı değişikliklerle 23 Nisan 1914 tarihinde Sadarete sunuldu. Yeni üç kaza kurulmasını içeren nezaret yazısında bu birimlerin teşkilatlandırılması için lazım olacak paranın 1330 yılı bütçesinin kaza faslında mevcut 66.600 kuruş ile buna ilave edilen 237.800 kuruştan karşılanmasının uygun olacağı belirtilmekteydi (BOA. DH. İ. UM. EK. 90/70: lef 9). Nihayet 4 Mayıs 1914 tarihinde çıkan irade-i seniyye ile sancak dâhilinde Korkudeli, Finike ve Manavgat adlarıyla üç kaza teşkil edilmesine karar verildi (BOA. A. DVNS. NZAM. d. 25: 83; BOA. DH. İ. UM. EK. 88/15; BOA. MV. 235/5). Yani mutasarrıflı̆ın teklifinde yer alan üç kaza 
kurulması önerisinin kabul edildiği ancak buralara Muradiye, Reşadiye ve Selimiye isimlerinin verilmesinin uygun görülmediği anlaşılmaktadır. Yine teklifte oluşturulması tasarlananlarla birlikte nahiye sayısının 31'e çıkarılması önerilmişken yeni idari düzenleme ile Teke Sancağı 26 nahiyeden meydana gelen bir mülki birim hâline getirilmiştir. Buna göre sancağın idari taksimatı şu şekilde oluşturulmuştur5:

\section{Antalya Kazası}

Merkez Nahiye (Merkezi Antalya Şehri)

Köyler-Nüfus: Antalya Kasabası (30.000), Zeytun (336), Varsak (691), Duacı (41), Duraliler (319), Çığlık (404), Bağçe (144), Karabayır Camili (200), Karaveliler (529), Ekşili (384), Döşemealtı (224), Kovanlık (411), Yedikuyular (213), Kütükçü (63), Yalınlı, Karahabit, Çakırlar (464), Hisarçandırı (531), Yarbaşçandırı (489), Çitdibi (104), Doyran (386), Bahşili (195), Sekici (30), Sekicikıbtisi (88), Kurma (311), Uncalı (61), Şerafeddinbayırı (167), Geyikbayırı (277), Aşağı Yukarı Karaman (321), Murtanada Macun (256), Kondu (477), Solak (267), Dumanlar (154), Alaylı (223), Çamköy (171), Kındıra (45), Asi Karaman (192), Mandırla (284), Karaçalılı (54), Murtanada Körlü (1.002), Murtanada İhsaniye (266), İstavroz (297), Abdurrahmanlar (266).

Serik Nahiyesi (Merkezi Kökez-Şevketiye)

Köyler-Nüfus: (Kökez) Şevketiye Karyesi (314), Karaboynuz (150), Boğaz Ak (259), Çakallık (259), Kumköy (154), Karıncalı (200), Candır (272), Pınarcık (156), Ayanoz (215), Cumalı (283), Kürüş (109), Ahmediye (245), Eminceler (194), Belek (98), Kadriye (266), Diğiş (146), Kocayatak (386), Şatırlı (209), Zaimler (120), Berendi (160), Yanköy (243), Kumbarlar (68), Belkız (132), Kuşlar (113), Gökçepınar (68), Akbaş (205), Bekuş (300), Çanakcı (171), Kayaburunu (210), Üçtepe (80), Aralık (80).

Gebiz Nahiyesi (Merkezi Macar Karyesi)

Köller-Nüfus: Macar (729), Tekye (235), Dorumlar (194), Hacı Osmanlar (114), Kozan (264), Kaşdanlar (Çetince) (250), Demirciler (195), Kızıllı (196), Karabaş (80), Pomaklar (250), Etler (116), Nebiler (149), Aşağı Oba (228), Çatallar (150), Çatma (72), Kürdler (300), Aksaz (107), Has Kızılören (580), Has Gebe (200), Has Duman (364) 
Kızılkaya Nahiyesi (Merkezi Badem Ağacı Karyesi)

Köyler-Nüfus: Badem Ağacı (983), Kuzköy (534), Uğurlu (285), Avdancık (204), Karapınar (402), Susuz (393), Boğazköy (150), Kökez (38), Yeni Çiftlik (62), Pazar Avdanı (586), Karaaliler (284), Kızılcaağaç (165), Hafız Bey Çiftliği (200), Dağ Mahallesi (877), Yuva (150).

Millü Nahiyesi (Merkezi Çil Karyesi)

Köyler-Nüfus: Çil (98), Karacaören (103), Gelesinli (231), Ortaköy (122), Fettanlar (33), Çamköy (57), Belen (19), Hacıceliller (81), Kavırgacılar (73), Köseler (79), Hatıblar (182), Kayadibi (52), Mevzeler (196), Karamanlı (33), Karg1 (230), Killik (396), Kızıl Seki (1.433), Kavacık (315), Kayı (382), Kocaaliler (938), Hacıhüseyinler (391).

Kemer Nahiyesi (Merkezi Kemer-Ağva Karyesi)

Köyler-Nüfus: (Ağva) Kemer (591), Beycik (85), Ulupınar (163), Tekfurova (136), Kozdere (139), Göynük (50), Beldibi (50), Ovacık (298). Kemer Nahiyesi Dâhilindeki Aşair: Yeni Osmanlı Aşireti (2.043), Sarıkeçili (2.423), Karahacilı (3.632), Karakoyunlu (1.343), Gebiz Aşairi (2.363), Murtana (2.295), Tahtacı (2.273), Eski Yörük Aşireti (1.452), Ahadlı (177), Çakal (196), Solaklı (36), Hacıhamzalı (552), Gönküşlü (542), Kömürciyan (95), Karatekeli (563), Fettahlı (255), Balıkcıyan (92).

\section{Alanya Kazası}

Merkez Nahiye (Merkezi Alanya Kasabası)

Köyler-Nüfus: Alaiye Kasabası, Oba (580), Oba Ala Kilise (187), Umurlu (95), Asmaca (88), Akdam (135), Avsallar (304), Basırlı (153), Badem Ağaç (440), Payalı (223), Cikcilli (137), Çıblaklı (226), Hacımehmedli (191), Değirmendere (241), Dere Türbelinas (619), Rumtaş (228), Toslak (959), Tosmur (245), Kara Kocalı (154), Kızılcaşehir (188), Gazgıcık (528), Kestel (432), Kürdler (387), Mahmudseydi (1.280), Mahmudlar (879), Yaylalı (285), Kızılağaç (732), Orhan (191), Ulucak (66), Aksin (43), Aydulun (44), Alara (116), Okurcalar (102), Bayır (243), Burcaklar (99), Çakallar (330), Sirke (176), Süleymanlar (374), Sarıağalar (39), Saburlar (133), Karamanlar (279), Karaboynuzlar (254), Kozağacı (160), Gözübüyüklü (95), Görenler (65), Günay (89), Yeniceköy (225). 
Demirtaş Nahiyesi (Merkezi Belen Karyesi)

Köyler-Nüfus: Belen (242), Kıllı (369), Sapadere (299), Çadupra (?), Gözüküçükler (181), Akçakaya (34), Eski Yörük (115), Yeni Dam (55), Domalan (138), Yularlı (148), İmamlı (120), Hocalar (120), İshaklı Aşireti (93), İsbatlı Aşireti (108), Bağçedere (72), Beldibi (79), Bayralı (212), Diğiş̧ (21), Seki (97), Şıhlar (496), Ali Efendi Aşireti (393), Keşaflı Aşireti (332), Çakırcalı (286), Koca Oğlanlı (103), Gönkeler (222).

Kara Halil Nahiyesi (Merkezi Öteköy Karyesi)

Köyler-Nüfus: Öteköy (128), Dim Ala Kilise (340), Kivrasil (?) (181), Beladan ( (87), Usta Ahmedli (56), Üzümlü (113), Bıçakcı (50), Bucak (147), Taşbaşı (171), Arablar (281), Kaya Beladan (223), Kozyaka (93), Setdere (135), Yalcı Yavaş (131).

Köprülü Nahiyesi (Merkezi Girenas Karyesi)

Köyler-Nüfus: Girenes (445), Eskibağ (265), Ortaköy (502), Bedan (299), Belester maa Yeni Saray (173), Çaltı (174), Cünedere (279), Nar Ağacı (101), Semet (453), Karaköy (85), Balor (526).

\section{Akseki Kazası}

Merkez Nahiye (Merkezi Marulya Karyesi)

Köyler-Nüfus: Marulya (3.447), Gelves (313), Çimi (1.477), Hüsameddin (200), Sarı Hacılar (208), Bucakkışla (125), Güneykışla (83), Akşahab (435), Pirlebe maa Kanarya (?) (282), Alavada (233), Belenilvad (701), Bucakilvad (172), İlvad-1 Kebir (839), Emir Aşıklar (294), Avdal (294), Sarı Halil maa Sarı Abbas (218), Didere (323), Gödene (790), Geriş (591), Yarpuz (798), Karavaganda (364), Ala Kilise (491), Çundura (174), Hoca (538), Kagras (799), Ciceler (282), Karakışla (275), Emiriye (207), Susuz Şahab (187), Hodarya (?) (137), Simyan (?) (449), Değirmenlik (239), Bademiye (659).

Sülles Nahiyesi (Merkezi Sülles Karyesi)

Köyler-Nüfus: Sülles (732), Manaval (203), Çaltıçukur (273), Efteşe (157), Kiliseli (261), Gödere (463), Karabul (135), Senir (453), Kara İsa (184), Sünbüle (144), Marnas (225), Namras (179), Serhenk (176), Göyüncek 
(247), Fersun (331), Cemerler (592), Kozağaç (285), Sindirfe (246), Narağacı (53), Eksere (721), Bergos (536), Aşağı Aşıklar (279), Viranyaka (341), Kizılköy (268), Kepez (447), Mudus (67), Günyat (372).

İbradı Nahiyesi (Merkezi İbradı Kasabası)

Köyler-Nüfus: İbradı Kasabası (3.520), Ormana (1.955), Unulla (594), Üzümdere (170), Başlar (216), Larma (495), Toros (155), Zilan (390).

\section{Manavgat Kazası}

Merkez Nahiye (Merkezi Manavgat)

Köyler-Nüfus: Manavgat Kasabası (270), Sarılar (540), Ilıca (268), Örenköy (44), Avason (428), Bucak maa Şıhlar (177), Peri maa Zeyve (182), Tilkiler (118), Hisar (72), Hatıblar (96), Homa (407), Hommaz (70), Dolbazlar (120), Seki (107), Sevinç (132), Şişeler (125), Salur (183), Sırt (319), Sorkun (190), Aşıklar (93), Kızılağaç (148), Kalemler (119), Kemer (108), Hinduge (39), Yavaş maa Örenler (91), Perakende Aşireti (233), Taş Ahırı (373), Bereket (71), Büklüce (67), Çardak (271), Çakış (166), Solaklı Aşireti (678), Hocalar (84), Düzağaç (514), Kızıldağ (380), Kısalar (87), Mecidiye (84), Nikit (199), Beydiğin (317).

Beşkonak Nahiyesi (Merkezi Bozyaka Karyesi)

Köyler-Nüfus: Bozyaka (401), Burmahan (129), Bolasan (320), Karabük (306), Tazı (191), Zerek (341), Kızılcaköy (448), Sağırin (132), Kepez (306), Karadut (66), Ballıbucak (252), Değirmenözü (312), Karabucak (128), Düzağaç (514).

Düşenbe Nahiyesi (Merkezi Pazarcı Karyesi)

Köyler-Nüfus: Pazarcı Karyesi (Düşenbe) (318), Çeltikci (194), Demirciler (149), Solak Aşireti (516), Aşıklar (1.201), Kirten (154), Karaöz (117), Gebece (207), Kadılar (98), Misırlar (328), Karacalar (159), Seydiler (130), Hacı İsalı maa Kıbtiyan Aşireti (1.038), Hacı Ali (117), Espiyeler (87), Kızılot (180), Boztepe (178), Karakaya (132), Çenger (133), Çavuşköy (187), Azavcalar (?) (176), Uzunlar (177), Boz Ahmedli (177), Hacı Obası (218), Saraçlı Aşireti (912), Balcı Dibi (119), Viransenir (179), Halidağalar (99), Alaybeyler (130), Odaönü (93), Ahmedler (273). 


\section{Korkudeli Kazası}

Merkez Nahiye (Merkezi Kışla Karyesi)

Köyler-Nüfus: Kışla (1.594), Kargalık (201), Emir-i Ahur maa Söğüdlü (241), Dat (98), Ak Kilise (343), Dere (487), Sülekler (562), Yazır maa Oyol (?) (617), Yeleme (670), Bayat (215), Ali Fahreddin-i Sağir (1.320), Taş Kesiği (488), Zivind (674), Andiya (736), Belen (336), Zivind Çarekesi (180), Gözer (245), Köseler (117), Çaykenarı (620), Yaka (192), Karataş (195), Fiğla (1327), Yelten (1.046), Kemerağzı (137), Karadiğin (71), Büyük Ali Fahreddin (1.320), Karakuyu (195), Çukurca (130), Leylek (173), Garibce (315), Kargin (284).

Kızılcadağ Nahiyesi (Merkezi Kızılaliler Karyesi)

Köyler-Nüfus: Kızılaliler (150), Yalınlı-1 Sağir (1.080), Yalınlı-1 Kebir (357), Duraliler (319), Çirkinoba (318), Çıvgalar (1.859), Ali Fahreddin-i Sağir Yaylası, Ali Fahreddin-i Kebir Yaylası, Karabayır (524), Beğiş (449), Avdan (694), Osman Halifeler (438), Mamatlar (184), Manay (354), İmamlı, Samandır (254), İmecik (763), Bağçe Yaylası (144), Çığlık (404), Karaman (321).

\section{Elmalı Kazası}

Merkez Nahiye (Merkezi Elmalı Kasabası)

Köyler-Nüfus: Elmalı Kasabası, Kozköy (81), Düdenköy (246), Kışlaköy (223), Bayındır (274), Ayvasıl (163), Yeni Çiftlik (131), Eymir (279), Tavullar (251), Beyler Çiftliği (146), Yalnız Alan (218), Eski Hisar (446), Momur (108), Çukun (258), Bayralar (370), Yazı (123), Tekye (324), Karamuk (96), Bucak (60), Sergiz (151), Çobana (127), Karaköy (243), Kızılca (334), Mürsel (96), Yuva (867), Gileveki (356), Ovacik (297), Avlan (45).

Kuzca Nahiyesi (Merkezi Gödene Karyesi)

Köyler-Nüfus: Gödene (400), Karaağaç (200), Gölcek (405), Karacaören (725), Kuzca (626), Kurk Direk (150).

Gömbe Nahiyesi (Merkezi Gömbe Kasabası)

Köyler-Nüfus: Gömbe Kasabası (500), Kızılağaç (152), Bayındır Yaylası (382), Barak Boğazcık (200), Kılınçlı (508), Afşar (127), Ahadlı (762), Ayvasıl (817), Armudlu (168), Değirmenköy (77), Akcainiş (242), Bayat (283), Dereboğaz Yaylası (284), Südleğen Akörü (450). 


\section{Kaş Kazası}

Merkez Nahiye (Merkezi Andifli Kasabası)

Köyler-Nüfus: Andifli Kasabası (336), Bayındır (390), Ağullu (111), Diğer İcadlı (767), Çukurbağ (702), Sırt (392), Pınarbaşı (52), Belekli (223), Kılınçlı (Çaycak) (508), Avşar (127), Yavı (346), Boğazcık (391), Çerler (98), Sarılar (308), Ahadlı (763), Kızılağaç (152), Akörü (1.285), Kendeve (405), Dere (178), Kasaba (1.167), Kemer (607), Dur Hasan (158), Mevlütler (257), Ortabağ (190), Yozgad (201), Ernez (389).

Kalkan Nahiyesi (Merkezi Ilıkra Karyesi)

Köyler-Nüfus: Hacı Oğlan (190), Ilıkra (645), Bezirgan (1.152), Kurnaz (323), İslamlar (1.316), Ova Gelemiş (195), Margaz (676), Çayköy (237), Kınık (497), Çavdır (446), Aklar (116), Çomburcu (451), Kurubükü (180), Bağliağaç (397), Arsa (387), Seydek (548), Kıbtiyan (88).

\section{Finike Kazası}

Merkez Nahiye (Merkezi Finike Kasabası)

Köyler-Nüfus: Finike Kasabası (694), Hallac (249), Demirciler maa Bağyaka (426), İncir Ağacı (322), Alacadağ (271), Yalnız (278), Harsköy (380), Yazır (418), Arif (563), Çavdır, Alasın.

Kumluca Nahiyesi (Merkezi Kumluca-Sarı Kavak Kasabası)

Köyler-Nüfus: Adrasan (181), Kumluca Kasabası (Sarı Kavak) (538), Belen (228), Yazır (252), Çıralı Ulupınar (110), Yeniceköy (440), Hacı Veliler (175), Savrın (231), Sarıcasu (165), Örtekiz (146), Salur (75), Kakas Kavakdibi (272).

Kale Nahiyesi (Merkezi Eynihal Karyesi)

Köyler-Nüfus: Kale maa Üçağızlı (229), Eynihal (377), Tirmison (307), Kapaklı (332), Gürses (180), Davaslar (376), Koca Temre (471), Kum (340), Beymelek (387), Matarlı (228), Köşkerler (415), Muşkar (350), Çağman (186), Karadağ (153), Dirgenler (256), Dağbağ (100).

Bağımsız Teke Sancağı sekiz kaza ve 26 nahiyeden oluşmaktaydı. Mutasarrıflığın teklifinde bahsedilen nahiyelerden merkez kazada Çandır ve Aksu, Alanya'da Gedikli, Korkudeli'de Bozova ve Akseki'de Kagras nahiyeleri kurulmamıştı. İğdir Kardiç nahiyesi üçe ayrılıp İğdir kısmında merkez 
kazaya bağlı Kemer ve Finike kazasına bağlı Kumluca nahiyeleri kurulmuş Kardiç kısmında ise Elmalı kazasının Kuzca nahiyesi tesis edilmişti (Güçlü 2007: 238). Yeni tesis edilenlerle birlikte nahiyelerin derecelendirilmesi de yapılmıştı. Buna göre sancağın birinci derece nahiyeleri Kemer, Gebiz, Serik, Demirtaşve Kalkan, ikinci derece nahiyeleri Millü, İbradı, Kuzca, Düşenbe, Beşkonak, Kumluca, Kale ve üçüncü dereceden olanlarda Kızılkaya, Kara Halil, Köprülü, Sülles, Gömbe ve Kızılcadağ olmuştur (BOA. DH. İ. UM. EK. 90/70: lef 32).

Fakat ilginçtir düzenleme öncesinde sancak içerisinde yer alan bazı köylerin listede bulunmadığı görülmektedir. Bunlardan Akseki kazasına bağlı olan fakat bu kazayla alakaları bulunmayan Yeniköy, Kirli, Gencek, Zekeriya, Derebucak ve Gönem köylerinin durumu önceden söz konusu edilmişti. Bu köylerin yakınlıkları ve ilişkilerinin daha çok Seydişehir ve Beyşehir kazalarıyla olması münasebetiyle bu kazalardan birine bağlanması hususu mutasarrıflı̆ı̆n ilgili raporunda ileri sürülmüştü. Hükümet bu görüşe hak vererek taksimat listesinde köylerin ismine yer vermemiş ve çıkarılan 5 Temmuz 1914 tarihli iradeyle de bu köylerin Seydişehir kazasına bağlanmasına karar verilmiştir (BOA, BEO 4297/322242; BOA. DH. HMŞ 30/95). Ayrıca sancağa bağlı olmasına rağmen listede bulunmayan bazı köylerin unutulduğu anlaşılmış (BOA. DH. İ. UM. EK. 90/70, lef 44) ve bunların ilgili nahiyelere bağlanması işi sancak meclis-i umumi kararına bırakılmıştır.

Teke Sancağı meclis-i umumisi yaptığı tetkikat ve müzakeratla idari taksimat sırasında unutulan köylerle birlikte bir-iki saatlik merkezlere bağlanması gerekirken yanlışlıkla sekiz-on saat mesafedeki yerlere dâhil edilen bazı köylerin durumunu ele almış ve bu köyleri yakın mülki birimlere bağlamıştır. Meclis-i Umuminin 17 Aralık 1914 tarihli mukarrerat kayıtlarına göre:

1. Mülki teşkilat sırasında unutulan Suğla, Simayuk, Elbağı, İmercik, Pir Hasanlar, Dire, Dere, Salur, Kurtan, Kecimen, Gökü, Mekran ve Macun köylerinin münasebeti itibariyle Elmalı merkez kazaya bağlanması

2. Çayiçi, Gerçan ve Dere köylerinin Kuzca nahiyesine bağlanması

3. Köleler köyünün Alanya kazasına bağlanması

4. Yeni tesis edilen Yalınlı Gediği köyünün Korkudeli kazasına bağlanması 
5. Mülki teşkilatta yanlışlıkla hem Kumluca nahiyesine hem de Kemer nahiyesine dâhil edilen Ulupınar köyünün Kemer'e bağlanması ve Kumluca'dan kaydının silinmesi

6. Mülki teşkilatta Sülles nahiyesine bağlanan Kepez, Kepez Beleni ve Mudus köylerinin Akseki merkez nahiyeye raptedilmesi

7. Mülki teşkilatta İbradı nahiyesine dâhil edilen Toros köyünün Akseki merkez nahiyeye bağlanması

8. Mülki teşkilatta Kızılcadağ nahiyesine bağlanan İmecik, Avdan, Samandır ve Beğiş köylerinin Korkudeli merkez nahiyeye dâhil edilmesine karar verilmiştir.

Meclis-i umumi ayrıca Manavgat kazasının merkezinin Düşenbe nahiyesinin merkezi olan Pazarcı köyüne taşınmasını da uygun bulmuştu. Esasen Manavgat namında bir kasaba ve köy olmayıp çay kenarında bulunan bir han ile iki-üç dükkândan ibaret bulunan ve etrafında mesken ve hane bulunmayan, haftada Cuma günleri pazar kurulan bir mahalle bu isim verilmekteydi ${ }^{6}$. Bu pazarı belirtmek için de Manavgat pazarı tabiri kullanılmaktaydı. Bu pazarın tam karşısında çayın öbür yanında Düşenbe nahiyesinin merkezi olan Pazarcı köyü bulunmaktaydı. Kazaya atanan kaymakam filen nahiye merkezi olan köyde ikamet etmekte ve vazife görmekteydi. Çayın iki tarafı kayıklarla üç-dört dakika olduğundan şekli muhafaza için Kaymakam günde bir-iki kere pazar mahallindeki hana gelip güya merkez kazada ispat-1 vücut etmekteydi. İşte bu manasız durumu düzeltmek için Meclis, kazanın merkezinde yer alan Pazarcı köyünü kaza merkezi yapmış ve Düşenbe nahiyesine bağlı Taşağıl köyünü de aynı adla anılmak üzere nahiye merkezi hâline getirmiştir.

Gerek unutulan köylerin idari birimlere bağlanması gerekse kaza içerisinde yapılan yeni düzenlemeler İdare-i Vilayât Kanunu'nun 3. maddesi mucibince meclis-i umumiye verilen icra yetkisi ile yapılmıştı. Oysa meclis, mülki teşkilatı ilgilendiren daha birçok karar almıştı. Ancak bunlar irade-i seniyyeye iktiranı lazım geldiği için öneri mahiyetindeydi (BOA. DH. İ. UM. EK. 90/70, lef 54). Bu önerilerin bir kısmı olumlu karşılanmış ve haklarında irade çıkarılmış bir kısmı ise karşılık bulmamıştır. Nitekim Teke Sancağı meclis-i umumisinin Alanya kazasına bağlı Nar Ağacı, Omalas, Penbelik köylerinin Akseki kazasına, Akseki'ye bağlı Namras köyünün Manavgat'a, Finike'nin Kale nahiyesine bağlı Dirgenler ve Karadağ 
köylerinin Kaş kazasına ve Kaş’ın Ernez köyünün de Finike’ye bağlanması yolundaki teklifleri 20 Nisan 1915 tarihinde kabul edilmiştir (BOA. MF. MKT 1208/14). Yine meclisin Elmalı kazasının Gömbe nahiyesinin lağvedilerek Korkudeli kazasında merkezi Zivind köyü olmak üzere Beğiş, Fığla, Garibce, Çukurca, Leylek, Karakuyu, Çaykenarı, Yakaköy, Yalınlı Gediği ve Zivind Çarekesi köylerinden mürekkep Bozova adıyla yeni bir nahiye kurulması önerisi de 21 Ağustos 1915 tarihinde uygun görülmüştür (BOA. DH. İ. UM. EK. 9/76; BOA. DH. İ. UM. EK. 94/43). Lağvedilen Gömbe nahiyesinin köylerinden Dereköy, Kızılağaç, Bayındır Yaylası, Barak Boğazcık, Kılınçlı, Afşar, Ahadlı ve Südleğen Akörü, Kaş kazasına ilhak edilmişlerdir (BOA. DH: UMVM. 123/17).

Meclis ayrıca sancak dâhilinde bulunan bazı kaza, nahiye ve köylerin isimlerinin değiştirilmesini de teklif etmişti. Önerilen isimleriyle beraber bu yerleşim birimleri şunlardı:

Tablo 3. Isimleri Değiştirilmesi Önerilen Yerleşim Birimleri

\begin{tabular}{llll}
\hline Mevcut İsmi & Önerilen İsim & Mevcut İsmi & Önerilen İsim \\
\hline Manavgat & Türkili & Bergos & Kaleli \\
Finike & Turanili & Gelves & Ali Paşa \\
Ala Kilise & Hatibler & Namras & Küçükköy \\
Geriş & Darülhayr & Viranyaka & Şeyh İdris \\
Kiliseli & Mersinli & Kagras & Dereköy \\
Karavaganda & Sadıklar & Toros & Madenköy \\
Sülles & Mecidiye & İstavroz & Boztepe \\
\hline
\end{tabular}

Meclis, Manavgat kelimesinin menşei bilinmediği ve bir anlam ifade etmediği gerekçesiyle değiştirilmesini ve kazanın tamamen Türklerden oluşması nedeniyle de buraya Türkili unvanının verilmesini teklif etmekteydi. Benzer bir gerekçeyle yani ahalisinin safi ve halis Türklerden ibaret olmasından dolayı Finike'nin de Turanili olarak adlandırılması istenmekteydi. Finike kelimesinin Konya'nın Feke ve sancağın ismi olan Teke ile karıştırıldığı, bu yüzden de isim değişikliğinin zorunlu olduğu vurgulanmaktaydı. Ayrıca Antalya merkeze bağlı İstavroz köyünün adının kurulu olduğu 
tepeye izafeten Boztepe olarak değiştirilmesi de önerilmişti. Çünkü ahalisi Müslüman olan köylüler memleketleri sorulduğunda İstavrozluyum demek zorunda kalmaktaydılar ve bu durumun düzeltilmesi de ancak köyün isminin değiştirilmesiyle mümkün olabilirdi. Akseki kazası idare meclisinin kazanın bazı köylerinin ihtisâsât-ı milliye ile kabil-i tevâfuk olmayan eski isimlerinin değiştirilmesi isteği de meclis-i umumice kabul edilerek teklifle sunulmuştu. İsim değişikliklerini içeren bu isteklerin o dönem için dikkate alınmadığı anlaşılmaktadır. Fakat Cumhuriyet Devri'nde bazı yerleşim birimlerinin isimlerinin değiştirildiği bilinmektedir?

\section{Bağımsız Teke Sancağında İdari Teşkilatlanma}

Bağımsız Teke Sancağı kurulduktan sonra işlerin yürütülmesini sağlayacak idari mekanizmanın hemen meydana getirilemediği ve kurumsallaşmanın zaman aldığı görülmektedir. Nitekim sancakta hususi idarenin kurulması ve yeterli memur kadrosunun oluşturulması hemen gerçekleştirilememişti. Kaldı ki ne sancak bütçesi tanzim edilebilmiş ne de bu işle vazifeli bir kurul olan meclis-i umumi teşekkül ettirilebilmişti. Teke Mutasarrıflı̆̆ bütçenin yapılabilmesi için en az üç aya ihtiyaç duyulduğundan bahsetmekteydi. Üstelik meclis-i umuminin toplanabilmesi için de bir dizi hukuki problemle baş etmek gerekmekteydi. Öyle ki Mutasarrıflık Konya Vilayeti Meclis-i Umumisi için seçilmiş olanların üyeliklerinin devam edip etmediği konusunda çelişkiye düşmüştü. Durum 21 Mart 1914 tarihinde Dâhiliye Nezaretine bir yazıyla soruldu. Nezaret, sancağın kazaları için diğer sancaklardan seçilmiş üye varsa bunların üyeliklerinin düşeceğini ve yeniden seçim yapmak gerektiğini böyle bir durum yoksa üyeliklerin devam edeceği cevabını vermişti (BOA. DH. UMVM. 64/44) ${ }^{8}$. Fakat bir süre sonra sancakta yapılan mülki düzenleme ile yeni kazalar tesis edilince buralarda seçim yapılması yeniden söz konusu oldu ve meclisin açılması işi uzadı. 1914 yılı yazında I. Dünya Savaşı'nın başlaması ve Osmanlı Devleti'nin 3 Ağustos'ta seferberlik ilan etmesi nedeniyle bir müddet daha gecikme yaşanmış ve nihayet meclis 23 Kasım 1914 tarihinde toplanarak bütçe yapma çalışmalarına başlayabilmiştir (BOA. DH. İD. 34/201-2: lef 30).

Teke Sancağı bütçesi hazırlanana kadar sancak, Konya Vilayeti Meclis-i Umumisinin 1914 yllı için meydana getirdiği vilayet bütçesinin Teke Sancağına ait kısmındaki varidât ve masarıfât dairesinde işleri yürütmüştü. Gerçekten de Teke Mutasarrıflığı, sancak bütçesinin hazırlanmasının uzun 
süre alacağı gerekçesiyle 17 Mart 1914 tarihinde Dâhiliye Nezareti’ne müracaat ederek sancağın idâre-i umuru için vilayet bütçesinden sancağı ilgilendiren kısmının tatbikine ve hususi idare henüz kurulmadığı için de hesap muamelelerinin mal memurları vasitasıyla yapılmasına izin istemişti (BOA. DH. İD. 34/201-2: lef 25). Nezaret, hesap işlerinin mal memurları tarafından yapılması uygun görmeyerek en kısa zamanda Maliye Nezareti'nden bir muhasebe-i hususiye müdürü talep edilmesine ve vilayet bütçesinin ilgili kısımlarının sancağa devrine karar vermiştir. Bunun için de Konya Vilayetine bir yazı gönderilerek bütçeden Teke Sancağına ait kısmın tefrik edilerek mevcut miktarın sancağa bildirilmesi istenmiştir (BOA. DH. İD. 34/201-2: lef 26).

Konya Vilayetinin 1914 yılı hususi bütçesi 21.798.024 kuruşluk gelir ve 23.611.718 kuruş tutan gider kalemlerinden oluşmaktaydı. Teke Sancağ için ayrılan miktar 4.200.000 kuruş gelir ile 4.000.000 kuruş giderden ibaretti. Her ne kadar gelir/gider dengesinde sancak avantajlı gibi görünüyorsa da vilayet bütçesinde öngörülen harcama kalemlerinin sancağın ihtiyacı ile uyumlu olmadığı tespit edilmişti. Nitekim Antalyảda 50 yataklı olarak sslah ve tanzimi düşünülen hastane ile yeni açılması planlanan Frengi hastanesine lazım olan tıbbi alet ve edevat ile karyolaların maliyeti için bütçe gider kalemine sadece 1170 lira konmuştu. Ayrıca bütçede ziraat depoları için 87 lira, ziraat muallimleri için 400 lira ayrıldığı ve bu miktarlarla işlerin yapılmasının imkânsız olduğu belirtilmekteydi. Yine maarife ayrılan paranın yeterli gelmediği ve işlerin şimdilik idareten yürütüldüğü vurgulanmaktaydı (BOA. DH. İ. UM. EK. 90/70: lef 48). Burada problem sancağın kendine ait bir bütçesi olmadığ için münakale yapamamasından ileri gelmekteydi. Yani bütçede gider kısmında yer alan fasıl ve maddelerden ihtiyaç olan bölümlere para aktarılabilmesi için irade alınması gerekiyordu. Oysa Sancağın vilayet bütçesi için böyle bir talepte bulunma hakkı yoktu. Neyse ki Teke Sancağı Meclis-i Umumisi 23 Kasım 1914 tarihinde toplanarak bütçe yapma çalışmalarına başlayabildi. Meclis' in meydana getirdiği 3.305.776 kuruş gelir ve 2.243.630 kuruş gideri havi 1914 yllı sancak bütçesi 13 Aralık 1914 tarihli irade-i seniyye ile yürürlüğe girmiştir (BOA. DH. İD. 34/201-2: lef 32).

Teke Sancağında bir taraftan hususi idarenin kurulması çalışmaları sürerken diğer taraftan sancağın genel yönetimini ilgilendiren konularda teşkilatlanma işleri yürütülmüştü. Öyle ki Hükümet, 19 Mart 1914 tarihinde sancakta 
bir istinaf mahkemesi ile bir de kaza bidayet mahkemesi teşkil edilmesine karar verdi. Ayrica Antalya İstinaf Mahkemesi Isparta ve Burdur sancakları için merci-i istinaf hâline getirildi (BOA. BEO 4269/320157). Mahkeme riyasetine Kütahya İstinaf Mahkemesi eski reisi Sadullah Bey, müddêิ-i umûmî görevine Konya Vilayeti İstinaf Mahkemesi eski müddeiumumisi Şerif Efendi ve azalıklarına Süreyya, Hulusi, Zaharya ve Kalust Reza beyler ve mülazımlığa Hacı Ali Bey getirildiler. Kaza Bidayet Mahkemesi reisliğine Ahmet Lemi Bey, müddeiumumiliğe Rauf Bey, azalıklara Mecdet ve Ermenak efendiler tayin edildiler (BOA. BEO 4269/320166). Sancak içerisinde Manavgat, Finike ve Korkudeli kazalarının teşkil edilmesinden sonra buralarda Nizamiye Mahkemeleri kurulması gerekmekteydi. Fakat bütçede tahsisat bulunmadığından gerek bu mahkemelerin tesisi gerekse adliye memurlarının tayinleri işi 1915 yılına bırakılmıştır (BOA. DH. İ. UM. EK. 90/70, lef 51).

Sancakta yönetim işlerini denetleyen mülkiye müfettişinin 19 Eylül 1914 tarihli raporundan anlaşıldığına göre her ne kadar sancak teşkilatlanmasında yol kat edilmiş olsa da yeni teşkil edilmiş olan üç kazada kaymakam ve tahrirat kâtibi dışında istihdam edilen hiçbir memur yoktu. Bu durum özellikle mal kalemi ve tapu işlerinde aksaklıklara neden olmaktaydı. Müfettiş, acilen buralara tayinler yapılmasını istemekteydi (BOA. DH. İ. UM. EK. 90/70, lef 49). Fakat sancak bütçesi hazır olmadığından ve genel devlet bütçesinde de böyle bir karşlık bulunmadığından işler yine sonraya 1915 yılına kalmıştır.

\section{Sonuç}

XX. yüzyıl başlarında Konya Vilayetine bağlı beş sancaktan birisi olan Teke Sancağı sahip olduğu geniş arazide büyük bir nüfusu barındırmaktaydı. Yerleşim daha çok iç bölgelerde yoğunlaşırken 350 deniz milini bulan kıyı şeridinde nüfus oldukça seyrekti. Mevcut idari teşkilatla ve eldeki personelle kıyılarda asayişi sağlamak ve kaçakçılığı önlemek imkânsızdı. Sancağın 600'e yakın köyü bulunmasına rağmen sadece beş kazası ve 11 nahiyesi mevcuttu. Üstelik vilayet merkezi oldukça uzakta bulunmaktaydı. Kış aylarında hükümet dairelerine gitmek zorunda kalan köylüler birçok sıkıntı çekmekteydiler. Teke Mutasarrıflı̆̆ı bu gerekçelerden yola çıkarak hükümete yeni bir idari düzenleme teklifi sundu. Buna göre kaza sayısı sekize, nahiye sayısı 31 'e çıkarılmaktaydı. Hükümet sadece sancak içerisinde 
bir düzenleme yapmak yerine Teke Sancağını Konya Vilayetinden ayırarak 12 Mart 1914 tarihinde bağımsız bir sancak hâline getirdi. Ardından Mutasarrıflğı̆ önerisini dikkate alarak bağımsız sancağın sınırlarını ve idari yapısını belirledi. Böylece sancak dâhilinde Korkudeli, Finike ve Manavgat adlarıyla üç yeni kaza teşkil edildi ve 15 yeni nahiye kuruldu. Hükümetin kısmî bir düzenlemeyle yetinmeyerek Bağımsız Teke Sancağını kurması sadece sancağın vilayet merkezine uzaklığıyla ilgili değildir. Bu hükümetin taşrada daha küçük, yönetilebilir idari yapılar oluşturma politikasının bir sonucudur.

Sancakta teşkilatlanmanın uzun ve meşakkatli olması hükümetin herhangi bir hazırlık yapmaksızın sancağı bağımsız hâle getirmesinden kaynaklanmaktaydı. Nitekim hükümet ile sancak arasındaki resmî muhabereye mahsus şifre miftahı bile 4 Nisan 1914 tarihinde yani bağımsızlık kararından 22 gün sonra gönderilebilmişti (BOA. DH. KMS. 19/21). Gerçekten de hükümet bir planlama yapmaksızın karar vermiş ve göç yolda düzülür mantığıyla teşkilatlanma işlerini sonraya bırakmıştı. Her ne kadar sancakta bir istinaf mahkemesi ile bir de kaza bidayet mahkemesi teşekkül ettirilmiş olsa da gerek adliye memurlarının tayini gerekse yeni kurulan kaza ve nahiyelerin personel atamaları genel bütçede karşılık olmadığı gerekçesiyle 1915 yılına bırakılmıştır.

Sancak bağımsız hâle getirildiği sırada elbette ki müstakil bir sancak bütçesi yoktu. Bütçenin hazırlanabilmesi için öncelikle hususi idarenin muhasebe kaleminin gelir/gider tespiti yaparak bunu meclis-i umumiye sunması gerekmekteydi. Meclis de müzakerelerle yıllık bütçeye son şeklini vermeliydi. Oysa sancakta henüz ne hususi idare kurulabilmişti ne de meclis-i umumi toplanabilmişti. Bu yüzden 1914 yılı Aralık ayına kadar sancak, vilayet bütçesine bağlı kalmak zorunda kaldı. Bu arada Maliye mektebi mezunlarında birisi muhasebe-i hususiye müdürlüğüne atanmış, bu birimde yeteri kadar memur görevlendirilerek muhasebe kaleminde gelir defterleri, yevmiye defterleri ve şehriye cetvelleri tutulmaya başlanmıştır. Meclis-i umuminin toplanabilmesi için de mutasarrıflık bazı problemlerin üstesinden gelmiş ve nihayet meclis kasım ayında bütçe yapma çalışmalarına başlamıştır. 


\section{Açıklamalar}

1. Tuna vilayetinde uygulanan Nizamname Tuna Vilâyeti Namıyla Bu Kerre Teşkîl Olunan Dâirenin İdâre-i Umûmiyye ve Husûsiyyesi ve Tảyin Olunacak Mémûrların Suver-i Intihâbiyeleriyle Vezẩif-i Dẩimesine Dẩir Nizâmnâmedir başlığıyla 7 Cemaziyülevvel 1281(8 Ekim 1864) tarihinde yürürlüğe girdi. Nizamname metni için bkz; Takvîm-i Vekâyi, Def'a 773 (7 Cemaziyülahır 1281); Düstûr (H.1282), I. Tertib, C. I, Matbaa-i Âmire: 517-554. Nizamnamenin çevrim yazısı için bkz; Mehmet Seyitdanlıŏlu (1996a). "Yerel Yönetim Metinleri III: Tuna Vilâyeti Nizâmnâmesi”. Çağdaş Yerel Yönetimler Dergisi V (2): 67-81.

2. Nizamnamenin çevrim yazısının ilk bölümü için bkz; Mehmet Seyitdanlığlu (1996b). "Yerel Yönetim Metinleri VI: 1871 Vilâyet Nizâmnâmesi ve Getirdikleri”. Çağdaş Yerel Yönetimler Dergisi V (5): 89-103 ve devamı için Mehmet Seyitdanlıŏlu (1996c). "Yerel Yönetim Metinleri VII: 1871 Vilâyet Nizâmnâmesi ve Getirdikleri”. Çağdaş Yerel Yönetimler Dergisi V (6): 89-99.

3. 1906-1907 yılı nüfus istatistiğine göre bağımsız sancaklar; Biga, İzmit, Zor, Kudüs, Çatalca. 1914 nüfus istatistiğine göre bağımsız sancaklar; Eskişehir, Antalya, Urfa, İçil, İzmit, Bolu, Canik, Çatalca, Zor, Kudüs, Karahisar-1 Sahip, Karesi, Kale-i Sultaniye, Kayseri, Kütahya, Maraş, Menteşe ve Niğde. Kemal H. Karpat (2003). Osmanlı Nüfusu (1830-1914). İstanbul: Tarih Vakfi Yurt Yay. 206, 226.

4. İstanos nahiyesi merkez olmak üzere yeni bir kaza oluşturulmasına yönelik 1893 yılından sonra birçok girişimde bulunuldu. Fakat bu girişimler askerî ve ekonomik gerekçelerle her defasında reddedilmiştir. Bu konuda geniş bilgi için bkz. Fahrettin Tizlak (2014). "Istanos Nahiyesi'nin Korkudili Kazası'na Dönüştürülmesi”. Akdeniz Insani Bilimler Dergisi (MJH) IV/2: 249-259.

5. Tabloda gösterilen yeni mülki teşkilât çıkan irade-i seniyyeye ek olarak BOA., A. DVNS. NZAM. d. 25, s. 84-96 da bulunmaktadır. Nüfus verileri BOA., DH. I. UM. EK. 90/70, lef 4'den alınmıştır. Köy isimlerinin okunmasında şu kaynaklardan yararlanılmıştır: Tızlak (2012). "Antalya ve Korkuteli’nin 1835 Tarihindeki Köyleri”. Dünden Bugüne Antalya. C.I. 131-134; Karaca 
(2012). "Dünden Bugüne Manavgat”. Dünden Bugüne Antalya. C. I. 413434.

6. Osmanlı kayıtlarında Köprüçayı ile Manavgat Çayının arasındaki bölge Manavgat olarak adlandırılmaktaydı. Bölge bir kaza ya da nahiye şeklinde teşkilatlandırılmıştı. 1530 tarihinden sonraki belgelerde Alanya’ya bağlı görülmektedir (Karaca 2012: 420-421).

7. Nitekim Dâhiliye Vekâleti tarafından Yer Adları Komisyonu'na hazırlatılan 1928 tarihli eserde bazı köylerin (Ala Kilise, Geriş, Sülles, Namras, Viranyaka, Kagras) yine eski isimleriyle anıldıkları görülmektedir. Hatta Geriş köyünün ismi günümüzde de aynen kullanılmaktadır. Fakat 1914 yılında Rumtaş adındaki köyün isminin eserde Türktaş olarak geçmesi bazı köy isimlerinin değiştirildiğini göstermektedir. Bkz; Dâhiliye Vekâleti (1928). Son Teşkilâtı Mülkiyede Köylerimiz. C. I. Ankara. 125-142.

8. 1913 yılı Konya Vilayeti Meclis-i Umumisinde Teke Sancağının dokuz üyesi bulunmaktaydı. Antalya kazası üyeleri; Edib zâde Mustafa Efendi, İbrişim zâde Mustafa Efendi, Civelek zâde Mustafa Efendi, Hoca Ahmet Efendi. Alanya kazası üyeleri; Talat Efendi, İzzet Efendi. Elmalı kazası üyesi; Ali Ragıp Efendi. Akseki kazası üyesi; Cevdet Efendi. Kaş kazası üyesi; Hacı Süleyman Efendi. Bkz. Salnâme-i Vilâyet-i Konya H. 1332: 163.

\section{Kaynaklar}

\section{Cumhurbaşkanlığı Osmanlı Arşivi (BOA)}

Bâb-1 Âlî Sadaret Divan Kalemi Nizamât Defterleri (A.(DVNSNZAM. d): No: $24 ; 25$.

Sadaret Divân-1 Hümayûn Kalemi Mukâvele Kısmı Belgeleri (A. DVN. MKL) 58A/96.

Bâb-1 Âlî Evrak Odası Belgeleri (BEO): 4269/320157; 4269/320166; 4297/322242.

Dâhiliye Nezâreti Hukuk Müşavirliği Belgeleri (DH. HMŞ): 30/95.

Dâhiliye Nezâreti İdarî Kısım Belgeleri (DH. İD) 34/201-2.

Dâhiliye Nezâreti İdare-i Ummiye Belgeleri (DH. İ. UM. EK): 9/76; 87/28; 88/15: 90/70; 94/43.

Dâhiliye Nezâreti Kalem-i Mahsûs Müdiriyeti Belgeleri (DH. KMS): 19/21.

Dâhiliye Nezâreti Umûr-1 Mahalliye-i Vilayât Müdiriyeti Belgeleri (DH. UMVM): 64/44; 123/17.

İrade Meclis-i Mahsûs Belgeleri (İ. MMS): 181/4.

Maarif Mektûbi Kalemi Belgeleri (MF. MKT): 1208/14. 
Meclis-i Vükelâ Mazbataları (MV): 235/5.

\section{Resmi Yayınlar}

Düstûr (1282). I. Tertib. C.I. İstanbul: Matbaa-i Âmire.

Düstûr (1289). I. Tertib. C.I. İstanbul: Matbaa-i Âmire.

Düstûr (1332). II. Tertib. C.V. İstanbul: Matbaa-i Âmire.

Salnâme-i Vilâyet-i Konya H. 1285, H. 1287, H.1317, H. 1332.

Takvîm-i Vekâyi, No: 773, 1414, 1760.

\section{Kitap ve Makaleler}

Atasoy, Veysel (1992). Türkiyéde Mahallî İdarelerin Yapısı ve Yeniden Düzenlenmesi. İstanbul: Türk Dünyası Araştırmaları Vakfi Yay.

Çadırcı, Musa (1991). Tanzimat Döneminde Anadolu Kentlerinin Sosyal ve Ekonomik Yapıları. Ankara: TTK Yay.

Çakmak, Biray (2014). “Osmanlı Taşrasında Yönetme ve Yönetilme Kaygıları: Uşak Kazasında Mülki-İdarî Değişim Talepleri ve Teşebbüsleri (1908-1919)”. OTAM Dergisi 36: 45-65.

Dâhiliye Vekâleti (1928). Son Teşkilâtı Mülkiyede Köylerimiz. C. I. Ankara.

Davison, Roderic H (2005). Osmanl Imparatorluğu'nda Reform 1856-1876. Çev. Osman Akınhay. İstanbul: Agora Yay.

Emecen, Feridun (1991). "Antalya”. İslâm Ansiklopedisi. C III. İstanbul: Türkiye Diyanet Vakfi Yay. 232- 236.

Güçlü, Muhammet (1998). "Müstakil Teke (Antalya) Sancağı'nın Kurulması ve İdari Düzenlemeye İlişkin Bir Belge”. Adalya 2: 289-300.

Güçlü, Muhammet (2007). “Selçuklulardan Cumhuriyet'e Kumluca (Antalya) Bölgesi”. Türkiyat Araştırmaları Dergisi 22: 219-250.

Faroqhi, Suraiya (2008). 19. Yüzyzl Başlarında Antalya'da Sosyal Hayat. Antalya: Antalya Büyükşehir Belediyesi Yay.

Karaca, Behset (2002). XV. ve XVI. Yüzyıllarda Teke Sancă̆ı. Isparta: Fakülte Kitapevi Yay.

Karaca, Behset (2012). "Dünden Bugüne Manavgat”. Dünden Bugüne Antalya. Antalya: T.C. Antalya Valiliği İl Kültür ve Turizm Müdürlüğü Yay. C. I. 413-434.

Karpat, Kemal H. (2003). Osmanlı Nüfusu (1830-1914). İstanbul: Tarih Vakfi Yurt Yay.

Kaştan, Yüksel (2016). “Osmanlı Devleti'nde '1913 Tarihli İdare-i Umumiye-i Vilayat Kanun-i Muvakkati’ İle Vilayet Yönetiminin Yeniden Yapılandırılması". Osmanlı Medeniyeti Araştırmaları Dergisi 2 (II): 78-98.

Kırmızı, Abdulhamit (2007). Abdülhamid'in Valileri. İstanbul: Klasik Yay.

Moğol, Hasan (1997). Antalya Tarihi. Ankara: Mehter Yay. 
Ortaylı, İlber (2000). Tanzimat Devrinde Osmanlı Mahallî İdareleri. Ankara: TTK Yay.

Ortaylı, İlber (2007). Türkiye Teşkilât ve İdare Tarihi. Ankara: Cedit Yay.

Özdemir, Rifat (1992). “Osmanlı Döneminde Antalya’nın Fiziki ve Demografik Yapısı (1800-1867)”. Tarih Incelemeleri Dergisi 7: 133-166.

Sencer, Muzaffer (1984). "Osmanlı İmparatorluğunda Tanzimat Sonrası Siyasal ve Yönetsel Gelişmeler”. Amme İdaresi Dergisi 3 (XVII): 46-71.

Seyitdanlığlu, Mehmet (1996a). "Yerel Yönetim Metinleri III: Tuna Vilâyeti Nizâmnâmesi”. Çăğdaş Yerel Yönetimler Dergisi 2 (V): 67-81.

Seyitdanlığlu, Mehmet (1996b). "Yerel Yönetim Metinleri VI: 1871 Vilâyet Nizâmnâmesi ve Getirdikleri”. Çăgdaş Yerel Yönetimler Dergisi 5 (V): 89103.

Seyitdanlığlu, Mehmet (1996c). "Yerel Yönetim Metinleri VII: 1871 Vilâyet Nizâmnâmesi ve Getirdikleri”. Çăgdaş Yerel Yönetimler Dergisi 6 (V): 89-99.

Tizlak, Fahrettin (2012). "Antalya ve Korkuteli'nin 1835 Tarihindeki Köyleri”. Dünden Bugüne Antalya. Antalya: TC. Antalya Valiliği İl Kültür ve Turizm Müdürlüğü Yay. C. I. 131-134.

Tizlak, Fahrettin (2014). "Istanos Nahiyesi'nin Korkudili Kazası'na Dönüştürülmesi”. Akdeniz İnsani Bilimler Dergisi (MJH) IV (2): 249-259.

Torun, Fatih Sadık (2012). "Osmanlı Taşra İdaresinin Yeniden Yapılanma Süreci (1842-1876)”. Karadeniz Araștırmalar Dergisi 32: 81-97.

Tönük, Vecihi (1945). Türkiyéde İdare Teşkilâtı. Ankara.

Uysal, Mustafa Ali (2010). "XIX. Yüzyılın İkinci Yarısında Bucak’ta İdari ve Sosyal Yapı”. Mehmet Akif Ersoy Üniversitesi Sosyal Bilimler Enstitüsü Dergisi 3: 103-119. 


\title{
Establishing of the Teke (Antalya) Sanjak as a Separate Unit by Parting from the Konya Vilayet and its Administrative Re- Organization $^{*}$
}

\section{Kerim Sançelik ${ }^{* *}$}

\begin{abstract}
Sanjak of Teke (Antalya), one of the five sanjaks of the Konya Vilayet in the beginning of the $20^{\text {th }}$ century had possessed an area of 22.370 square kilometers and a 350 nautical miles of coastline. Its population was about 250.000. With this position it had constituted a geographical unit which was bigger than many separate sanjaks and even some vilayets. In spite of this, insufficient organization of the sanjak which is incompatible with its size and its long distance to the provincial center Konya had caused serious troubles in the administration. This situation revealed the need of a new administrative organization. Besides this, the provincial law of 26 March 1913 had brought a new understanding of governance which was based on smaller, manageable administrative units. With all these reasons, Sanjak of Teke had been established as a separate unit by parting from the Vilayet of Konya on 12 March 1914. Administrative organization in the detached sanjak followed a long and troublesome path. In this process, new districts (kaza) and subdistricts (nahiye) had been formed. In these areas it has been tried to establish new civil service units and their staffs. On the other hand special sanjak administration had been found, general council of the sanjak had assembled and set to work for the preparation of the sanjak budget.
\end{abstract}

\section{Keywords}

Sanjak of Teke, detached sanjak, civilian dministration, local administrations, special administration.

\footnotetext{
Date of Arrival: 22 January 2017 - Date of Acceptance: 15 August 2017

You can refer to this article as follows:

Sarıçelik, Kerim (2020). “Teke (Antalya) Sancağının Konya Vilayetinden Ayrılarak Bağımsız Hale Getirilmesi ve İdari Yönden Yeniden Düzenlenmesi”. bilig - Journal of Social Sciences of the Turkic World 93: 85-114.

** Assoc. Prof. Dr., Necmettin Erbakan University, Ahmet Keleşoğlu Faculty of Education, Department of History Education - Konya/Turkey ORCID ID: 0000-0003-2827-6132

ksaricelik@erbakan.edu.tr
} 


\title{
Выделение независимого санджака Теке (Анталия) из вилайета Конья и его административная реорганизация*
}

\author{
Керим Сарычелик*
}

\begin{abstract}
Аннотация
Санджак Теке (Анталья), в начале 20-го века один из пяти санджаков вилайета Конья, имел площадь 22,370 квадратных километров и береговую линию длиной 350 морских миль. Его население составляло около 250.000 человек. По этим показателям он превосходил многие отдельные санджаки и даже некоторые вилайеты. Несмотря на это, недостаточная организация санджака, несовместимая с его размерами и его большим расстоянием до центра провинции Конья, привела к серьезным проблемам в администрации. Эта ситуация выявила необходимость новой административной организации. Кроме того, провинциальный закон от 26 марта 1913 года привел к новому пониманию управления, которое основывалось на меньших, управляемых административных единицах. Исходя из этих причин санджак Теке был создан как самостоятельная единица, путем выделения из вилайета Конья 12 марта 1914 года.

Административная организация в выделенном санджаке шла по долгому и хлопотному пути. В ходе этого процесса были образованы новые районы (каза) и субрайоны (нахие). В этих районах пытались создать новые подразделения государственной службы и их персонал. С другой стороны, было образовано специальное управление санджаков, собрался генеральный совет санджаков, и была начата работа по подготовке бюджета санджаков.
\end{abstract}

\section{Ключевые слова}

Санджак Теке, отдельный санджак, гражданская администрация, местные администрации, специальная администрация.

\footnotetext{
" Поступило в редакцию: 22 января 2017 г. - Принято в номер: 15 августа 2017 г.

Ссылка на статью:

Sarıçelik, Kerim (2020). "Teke (Antalya) Sancağııın Konya Vilayetinden Ayrılarak Bağımsız Hale Getirilmesi ve İdari Yönden Yeniden Düzenlenmesi”. bilig - Журнал Гуманитарных Наук Тюркского Мира 93: 85-114.

** Доц., д-р, Университет Неджмеддина Эрбакана, педагогический факультет имени Ахмета Келешоглу, кафедра преподавания истории - Конья / Турция ORCID ID: 0000-0003-2827-6132

ksaricelik@erbakan.edu.tr
} 